\title{
PEDAGOGICAL TECHNOLOGIES OF TEACHING FOREIGN LANGUAGE
}

\author{
Zhangul Togtoomurat ${ }^{1}$, Zhanar Eskazinova ${ }^{2}$ \\ ${ }^{1}$ E.A.Buketov Karaganda University, Karaganda, Kazakhstan \\ ${ }^{2}$ E.A.Buketov Karaganda University, Karaganda, Kazakhstan \\ ORCID (iD:0000-00018863948X
}

\begin{abstract}
In this article, we will talk about methods and technologies of teaching foreign languages. Based on life experience, the disadvantages, and one - sided nature of some methods lead to the fact that they do not give a positive result in mastering foreign languages, although the students are fluent in grammar, as a result, they are unable to speak and think in the language they are learning. In order to eliminate these gaps, it is proposed to use effective methods of teaching students to the extent that they can use foreign languages in their lives, to practice non-thinking speech skills, and to achieve a level of thinking in the language they are learning.
\end{abstract}

\section{INTRODUCTION}

"You can buy in any language, but to sell you have to speak their language"

U.S. A.

The more correctly teachers can show students effective ways to learn foreign languages, the higher the result will be. This shows how important methods play in the study of foreign languages. After carefully studying and observing the results of the methods used in the lesson, I would like to highlight the shortcomings of many methods. In addition, effective and high-quality methods will be presented. The effectiveness of the methods used in the learning process is measured by the achievements of students [Goletiani et al, 2021; Valdmane et al, 2020; Linde \& Petrova, 2018]. This means that by monitoring the level of foreign language proficiency of our students, teachers can determine how correct and effective our methods are. A good teacher contributes to the improvement of students' knowledge. The teacher can give different tips and methods in learning foreign languages. Teachers should use more effective method.

One very interesting method is called "one topic-different ways of listening". To put it bluntly, the essence of this method is to learn the same topic by listening repeatedly from different sides.

Listening to one topic means listening to one topic in many different ways. This is a much stronger approach than listening to many topics without a plan. A student who listens to one topic in many different ways, learns to speak well in a very short period of time. A set of vocabulary and phrases is used in a certain range to express one subject from multiple points of view. In other words, it has the advantage of using synonyms. Therefore, it is easier to understand. Eventually, students can automatically memorize these phrases and automatically start using them in their speech. Teachers should guide students on the right path of achievement, give them advice at learning foreign languages. For example: If you don't understand what you're hearing, you won't learn anything. Never improve. It's like watching TV in English, but your level doesn't improve. You ignore most things. Because it's hard to understand, or because it's a phrase that you've never heard before, that you don't know.If you don't understand, you won't learn! If you hear new words once, they will instantly be forgotten. Even if you hear 5 times, you forget. So how often can we make sure that we are not forgotten? Most people identify the new word after hearing it 30 times. It is necessary to listen 30-50 times to understand a word immediately after it is said. In summary, there are two most important aspects of learning English: first, listening to what is perceived to be heard, and second, listening to it repeatedly. "Listen to a topic; - do not worry if you do not understand. Just listen to it many times. 
You will automatically understand. You must work on the topic before you start listening and you need to know the meanings of all new words. It will help you understand and identify words and phrases when you listen to a topic. By repeating the text several times, you will learn the words and phrases in this text and will be able to use it in life as well.

"One-sided methods" is to pay great attention to the study of grammar. If much attention is paid to the study of grammar, then this will lead to a situation where students cannot apply their knowledge in life because they do not have developed the ability to speak or listen. The main reason why students can't speak is because they only learned the rules. But in fact, this is the most wrong way of learning! The reason: firstly, learning grammar is a one-sided method, and secondly, it does not develop speech skills. Because before students speak, they think about how to speak correctly according to the rules. When we speak in our native language, we do not think about what rules we are speaking. If we start thinking, we also can not speak. The main reason is this.

Another effective way is to align "reading with listening". This easy but highly effective method. In my experience, students know grammar well, but they can't do anything other than write a simple sentence in a very limited context. Because they don't have enough vocabulary, they can't articulate what they're writing. I tell my students that if you really like reading, you should never read textbooks or study books. Instead, you can read fairy-tale books or prose books for children aged 1015 , or easily written novels. This will at least increase vocabulary and allow students to get a deeper understanding of how sentences are written. If teachers use a parallel approach to reading and listening, they will be able to develop their students ' listening skills and reading comprehension skills. It's an absolutely plain and easy way. Students should only listen to the English-American talks, lessons, books, and posts along with the original text. In parallel with reading and listening, students ' pronunciation will improve. Also, reading while listening is deeply ingrained. After several parallel reading and listening exercises, students should only listen without using the reading material. At this point, students will be able to understand and their language skills will improve very quickly. In other words, teachers need to teach their students how to listen over and over again. By listening to it repeatedly, students will make their own use of all the material they hear. The method of reading and repeated listening is useful for gaining deep knowledge.

The next method is teaching the rules. So, let's first look at what the rule is. If the student can correctly express his sentences at different tenses, such as Past, Present, Future, that means the student can speak correctly. For example, I talked to him. I was talking to him for 3 hours. I had been talking to him for 3 hours before he saw the right road. I will talk to him. I will be talking to him. I will have been talking to him for an hour. So how to learn these rules quickly and correctly? Here is the secret of this method. Let me clarify a little bit. A teacher takes a little story or an argument as the main topic of a lesson. This story is written in the present tense, which defines recurring things as "the sun rises, "water flows" and so on. After listening regularly, students will begin to understand what tense it is. For example, the boy's name is Arman. He buys water from the store. The price of water is 100 tenge. He pays the seller 100 tenge. He goes home. - suppose this very simple little item is the subject of the lesson. This is just an example. It's much more difficult, much harder, much longer to teach students this rule. Students understand the rules, but they can't apply them in life. Also, when students listen to this story, they can fully understand it and use in their daily life.

But if the teacher will write the same story in the past tense: "The boy's name was Arman. The boy bought water at the store. The price of water was 100 tenge, so he paid the seller 100tenge. Then students assimilate the material well.

Also, the teacher can write the same story in the future tense:" The boy's name will be Arman. The boy will buy water. The price of water will be 100 tenge, so boy will pay the seller 100 tenge. Then he will go home.

Or: "There was a boy named Arman. Since last year, he has been going to the store for water. Every time he bought water at the store, he has paid the seller 100 tenge. Then the boy has gone home..." -can be written in the different tenses.

The primary goal should be for the students to hear and understand directly, and to be able to use it on their own. In these comparative examples or little stories, students begin to understand the 
time difference in a very organized way. Just like a native speaker, it will automatically begin to understand. They will never forget, nor memorize without confusion. Just listen, for example, listen in the past, listen in the present, listen in the future, listen in the mix, etc. In the end, students will be able to speak $100 \%$ exactly according to the rules.

Most teachers teach their students in a "listening - imitating" way. For example, a teacher might say, "all right, please imitate me, "Hi, how are you?" all of the children in the class were like, "Hi, how are you?" says. The teacher says, "I'm fine, and you?", the children say, "I'm fine, and you?". The students imitate. This is an outdated method. Because students don't think in language, they learn, they don't think about what they're saying, they just imitate it. This is an outdated teaching method.

The method is "Listen - Answer". In other words, the little story that is the subject of the lesson is asked by the teacher in so many different ways with so many different questions, and the students answer. Of course, the teacher will also say the correct answer. In other words, the teacher asks questions, the student answers them, and so on. Exactly real conversational communication is created by the teacher. Students start answering immediately after 2 weeks without thinking. In other words, students begin to understand and respond immediately. Answering without thinking means that students begin to think and answer in the language they are learning. This is the super fastest way to learn to speak. In general, it is necessary to speak to learn to speak, and it is necessary to listen to a lot in order to understand directly. Very simple rules.

Is there an effective method to learn new words quickly and for a long time? Do not memorize the words alone. Memorize any word with the word that is used together, so that it will be handy to put into use later. For example, the word "wool" should be memorized as "sheep's wool". Memorizing conjugated words makes it easier to stay in the mind and put it into a sentence. Teachers need to understand that no person speaks a word. This is why students need to memorize in context, in sentences. When I learned English as a child, my teacher never allowed me to answer a question in one word. "No" instead of the answer is "No, I don't like belly button rings", "No, I haven't seen that movie yet. I was asked to answer in full sentences, such as". It was only after becoming a teacher that I realized the importance of this and thanked the teacher.

Another interesting method is "the use of Cards". Very attractive to students. Write English words on one side of the card and the translation on the other side. The students look at the translation and remember the words, which must be included in the short sentence. When you make a sentence, you can include the names of people in your family or link them to real life. Because more remains in the mind. The students then write down the words related to that word, words with the same and opposite meanings, plural and pronunciation.

One more way that students like is "to practice alone and talk to themselves". Stand in front of a mirror and tell yourself what you are doing right now, or sing in the language you are learning. If it's hard for you, look at some words and you'll be able to do it again. If you cook, remember phrases about food and describe your actions. So, you can continue your exercises in the bathroom and in the bedroom. This approach can strengthen students' ability to speak and give them the opportunity to believe in themselves.

"Record and listen to your speech". Students should record a small TV show, intermission or movie on your mobile phone and listen carefully. Then simulate a "game". They need to write down what they say and compare it. Repeat what is wrong until it becomes right. Little by little, students' speech will become more and more like their "prototype". It's like little kids imitating adults.

This method is most convenient if students use the application SoundCloud.

"Read aloud". Reading aloud increases speech skills more than talking to a person in normal times. Students will have 5-10 minutes to listen to what they're talking about and understand exactly which areas you need to focus on. Then students should practice on those parts.

"Listen and listen". In order for students to develop speaking skills, they must first develop listening and reading skills. This is the basis of students' ability to speak. What does it really mean to speak? Listening means that you absorb the other person's speech as an example. So, the more we listen, the better we talk. 
"The internet and a tablet." There are many applications that students can use online and on tablets to improve their language skills. I think teachers need to know these apps and recommend them to their students to use these apps for language learning.

1. Lingualeo. An application of a popular service with a lot of various training that will help expand vocabulary, as well as develop reading, writing, and listening skills. The training is based on gamification, so you will not lose interest in English, you will constantly feel progress and an incentive to move on.

2. Duolingo. A convenient application, thanks to which you can playfully learn English, spending only a few minutes a day. Start with simple verbs and phrases, practice your grammar, and complete daily tasks to replenish your vocabulary and get closer to your goal.

3. Polyglot 16. The application is from the author of the course of the same name, the famous polyglot Dmitry Petrov. According to the developer, the program allows you to master English at a basic level in just 16 lessons. By devoting at least 15 minutes to learning every day, you will learn the rules of grammar, memorize the necessary minimum of words and learn how to make up a lot of phrases from them for free communication with native speakers.

4. Memrise. Another application with an unusual game approach that will turn learning English into fun and make it easy to memorize new words.

5. BBC Learning English. The official application of the BBC, which contains materials of various programs for learning English, which were broadcast on the radio and in the podcasts of the broadcasting corporation. In addition to audio content, various exercises are available for understanding grammar, constructing phrases, and mastering new words.

6. Easy Ten. With this program, you will be able to replenish your vocabulary daily by memorizing 10 new words. The application does not require much time: it is enough to devote 20 minutes a day. The program contains more than 20 thousand English words, will help you improve pronunciation thanks to special simulators. In addition, you can divide new words into thematic lists and track progress for additional motivation.

7. Words. It is no coincidence that this app has become the best in the "Education" category of the app store. The database of the program contains more than 8 thousand words, and it is available offline.

8. LearnEnglish Grammar. The application of the British Council organization is for everyone who wants to improve their English. It focuses on learning grammar and helps to make progress at any level. Work through the exercises, answer the test questions, and practice building phrases on various topics.

9. Rosetta Stone. This app helps you memorize new words thanks to associations. The pronunciation assessment program will help you learn how to pronounce the words you have learned correctly. The application is available for free, but there are also paid materials.

10. Voxy. The main difference between this application and all the others is that it adapts to your needs and desires in real-time. Do you want to prepare for TOEFL? Or learn phrases that will be useful on the journey? Or maybe prepare for an interview? You are welcome! Mentors who are native speakers will promptly help you with this. In addition, the application is updated daily.

11. Rememba. A simple and convenient application that is specially created for memorizing new phrases and expanding vocabulary. The learning process is based on a proven method of cards, which, after being added, are displayed less often or more often as they are assimilated. You can add words manually or use ready-made dictionary sets.

12. English Grammar in Use. A program from Cambridge University Press will help you improve your grammar skills. With the help of English Grammar in Use, you can bring the use of articles, irregular verbs, and nouns to automatism.

13. 15000 Useful Phrases. The dictionary application contains more than 15,500 interesting idioms that are often used in the process of live communication. Aphorisms, words, comparisons, and much more you can use when communicating at the household level and in the professional and business sphere. 
14. WordBook. A real treasure trove, not just a dictionary that can be on your smartphone: 150 thousand words, spell checking, and the ability to search for words to create anagrams. In addition, every day you will memorize the word of the day that the application will offer you. The dictionary is available offline.

15. Puzzle English. An exciting application with video and audio tasks, as well as other interesting tasks for mastering English, regardless of your existing skills. The training program is compiled individually depending on the level of proficiency, available time, and set goals.

\section{CONCLUSIONS}

I included free application that I offer to my students. It is very interesting for students and allows students to learn at any time.

In conclusion, teachers should use various modern methods of teaching foreign languages. This affects the quality of work and achievements of students in learning foreign languages. It is very important that teachers always improve their teaching skills and be aware of the latest professional innovations.

\section{REFERENCES:}

Goletiani, K., Mushkudiani, Z., Gulua, E., Janelidze, N. (2021). Difficulties in managing diversity in Georgian educational organizations. Access to science, business, innovation in digital economy, ACCESS Press, 2(2): 123-137. https://doi.org/10.46656/access.2021.2.2(1)

Linde, I., Petrova, M. (2018) The challenges of formalization and modeling of Higher Education Institutions in the 21st century. CBU International conference proceedings 2018: Innovations in Science and Education, 21.-23.03.2018, pp.303-308, https://doi.org/10.12955/cbup.v6.1173

Lynne Cameron. (2001) Teaching Languages to Young Learners // Cambridge University Press

Penny McKay and Jenni Guse. (2007) Five-Minute Activities for Young Learners // Cambridge University Press

Valdmane, L., Zarina, S., Iliško, D., Badjanova, J., Petrova, M. (2020). Empowering of digital and media literacy of primary school teachers in Latvia. EDULEARN20, 12th annual International Conference on Education and New Learning Technologies, 6th - 7th of July, 2020, https://iated.org/edulearn/; Proceedings of EDULEARN20 Conference 6th-7th July 2020, ISBN: 978-84-09-17979-4, ISSN: 2340-1117, pp.4022-4029, DOI:10.21125/edulearn.2020, Publisher: IATED; $10.21125 /$ edulearn.2020.1087

WILLIAM O’GRADY. (2005) How Children Learn Language // Cambridge University Press 